\title{
Sustainability Indicators For Fishery Management In Songkhla Lake, Thailand
}

\author{
Narit Doungsuwan, Prince of Songkla University, Thailand \\ Chatchai Ratanachai, Prince of Songkla University, Thailand \\ Penjai Somgpongchaiyakul, Chulalongkorn University, Thailand \\ Prapaporn Sangganjanavanich, Prince of Songkla University, Thailand
}

\begin{abstract}
This paper describes the development of a set of indicators for monitoring sustainable fishery management in Songkhla Lake, Thailand. Data and information for developing these indicators were collected through questionnaires administered to fishermen, interviews of other stakeholders, and focus group discussions among experts. The results revealed ten significant monitoring indicators, which are grouped into four categories - five ecological, one economic, two community, and two legal and institutional. They were selected so as to obtain the minimum number of indicators and to obtain indicators that are understandable, applicable, precise, sensitive, and linked to sustainability. They are expected to provide a useful tool for supporting the decision-making process of relevant organizations and achieving sustainable fishery management in Songkhla Lake.
\end{abstract}

Keywords: Indicators; Sustainable Fishery; Songkhla Lake

\section{INTRODUCTION}

\subsection{Overview}

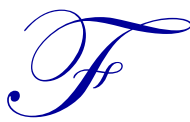

ishery resources have long been a crucial source of food for hundreds of millions people worldwide. The Food and Agriculture Organization (FAO) of the United Nations reported that in 2005, fish was the sole source of protein for 80-90 million people in developing countries. The global marine catch increased from 16.7 million tons/year in 1950 to 62 million tons/year in 1989 and 84.4 million tons/year in 2002. However, it decreased to 80 million tons/year in 2008. It has become clear that global fishery resources have been overexploited (Hosch et al., 2011; Srinivasan et al., 2012; Ukwe et al., 2006). In fact, the catch has been about $30 \%$ over capacity (FAO, 2012). This is attributed to a lack of effective management (Coulthard et al., 2011) and continuing competition for fishery resources (Pomeroya et al., 2007). The marine catch has been intensive, even in the deep sea (Norse et al., 2012). Moreover, fishery resources have also been depleted as a result of household and industrial pollution (Ukwe et al., 2006). World fishery resources are now reaching the tipping point and appear to be unsustainable, and Thailand is no exception. Overfishing of both pelagic and demersal fishes has been observed since 1987 (Tokrisna, 2005).

\subsection{Songkhla Lake and Fishery}

Songkhla Lake is the largest lagoon lake in Thailand and is located near the east coast of southern Thailand. It has an area of $1,042 \mathrm{~km}^{2}$ and consists of four parts: 1) a freshwater lake called Thale Noi in the northern part, 2) Upper Songkhla Lake, 3) Middle Songkhla Lake, and 4) Lower Songkhla Lake which connects to the Gulf of Thailand (Sirichai and Doungsuwan, 2009) (see Figure 1). The marine catch obtained using 15 types of fishing gear totaled 9,634 tons/year in 1995, which was $21.63 \%$ less than the catch in 1985 (Choonhapran, 1996). A fish landing survey conducted in 50 ports around Songkhla Lake during 2003-2009 by the National Institute of Coastal Aquaculture (NICA) showed that approximately 100 species of fish were landed; the catches of 27 species increased, whereas those of 53 species decreased, and the catches of the other species remained stable. The study 
revealed that in tonnage, the catch decreased from $1,380,694 \mathrm{Kg}$ in 2003 to $1,013,526 \mathrm{Kg}$ in 2009 , a decrease of $26 \%$ (NICA, 2010).

The development of indicators for monitoring sustainable fishery management will enhance coordination, information sharing, and conflict resolution among different sectors. Moreover, these indicators can be used by policy-making agencies to formulate strategies for fishery management in Songkhla Lake.

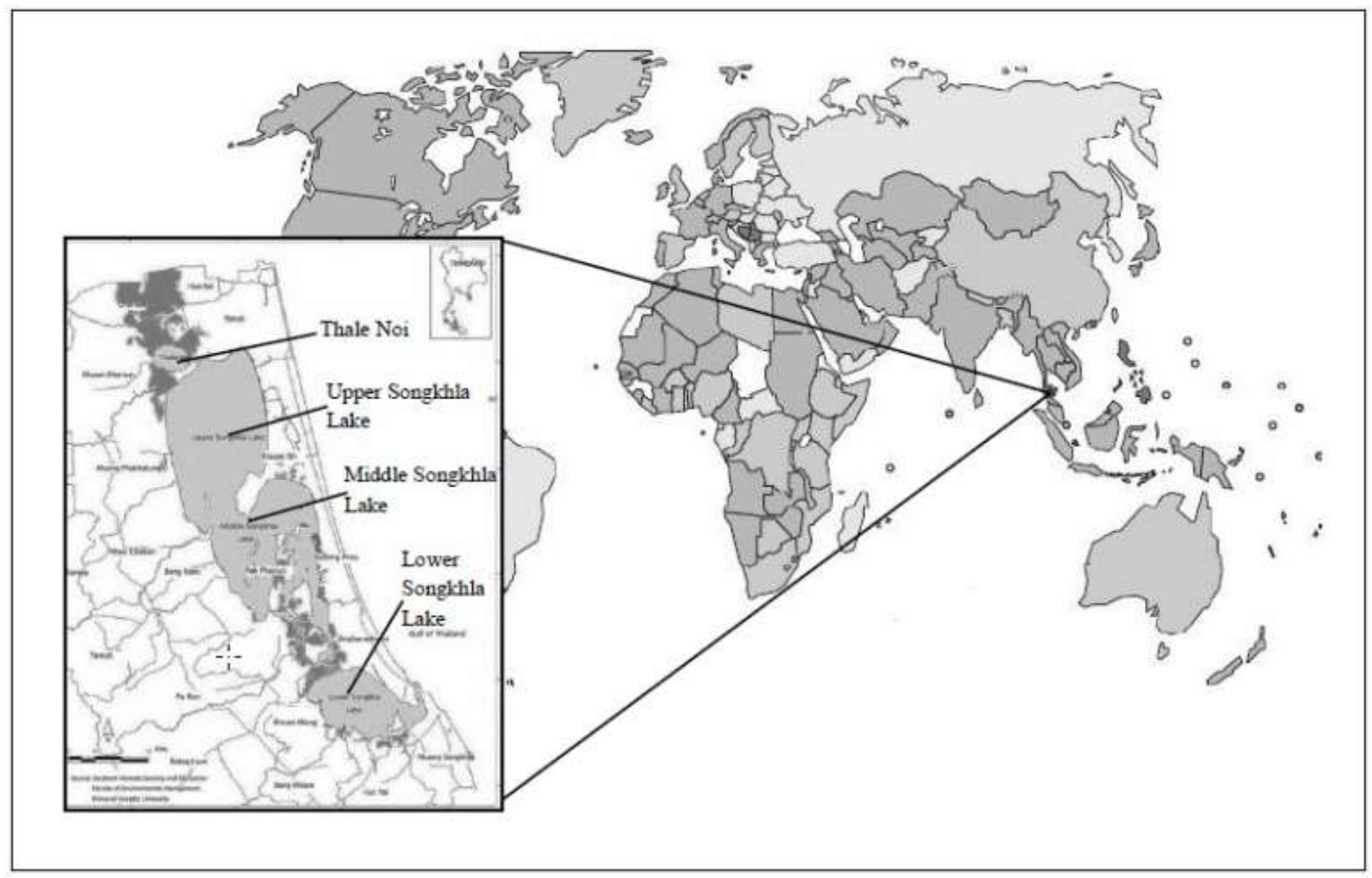

Figure 1: Songkhla Lake's Four Components

\subsection{Sustainable Fisheries}

FAO defined fishery sustainability as "the balance of fishery resource conservation with human needs" (FAO, 1999). An important framework for sustainable management of fishery resources is the Code of Conduct for Responsible Fisheries, which emphasizes the balance between the environment and human needs. The main components of the framework are fishery management, fishing operations, aquaculture development, integration of fisheries into coastal management, the fishery industry and trade, and fishery research (Garcia and Staples, 2000). Charles (2001) and Fletcher (2002) also noted that sustainability factors for fisheries include the richness of fishery resources, human well-being, and effective management of fishery resources.

\subsection{Development of Indicators for a Sustainable Fishery}

The indicators for a sustainable fishery should demonstrate causes and effects, the fishery status, and the development of the fishery system. They can be used to assess the quality and efficiency of fishery and aquaculture resource management in order to improve policy-making regarding fishery system management (Gallic, 2002; Zenetos et al., 2002; Raakjaer et al., 2007). They provide a useful tool for assessing the efficiency of policies related to fishery management at all levels, evaluating progress on developing sustainable fishery processes, and increasing the quality of communication, transparency, and responsibility in fishery management, as well as monitoring and assessing fishery sustainability (Vandermeulen, 1998; FAO, 1999; Gallic, 2002; Boyd and Charles, 2006). 
Four aspects of fishery sustainability must meet sustainable development requirements - ecosystem, socioeconomic, community, and institutional sustainability (Charles, 1994). These aspects were used as the framework for developing the indicators. Important criteria include understandability, ease of measurement, accuracy, reasonableness and practicability, acceptability, and emphasis at the policy level (FAO, 1999; Garcia et al., 2000; Boyd and Charles, 2006; UNESCO, 2006).

The FAO (1999) summarizes a two-step process for developing sustainability indicators. The first step is to determine the scope and identify the measured criteria in general terms. The second step is to develop and apply the indicators. The information used to develop the indicators consists of qualitative and quantitative data from questionnaire surveys, the opinion of experts and stakeholders, and the traditional knowledge of communities.

\section{OBJECTIVE AND METHODS}

\subsection{Objective}

This research is aimed at developing indicators of sustainable fishing and to propose policy recommendation for fishery management in Songkhla Lake.

\subsection{Methodology}

\subsubsection{Data Collection}

1. Questionnaire surveys of 200 fishing households in 21 sub-districts around Songkhla Lake were conducted in 2010. The interviewees were randomly sampled from 3,326 fisherman households.

2. Semi-structured interviews of 16 representatives of academia, government organizations, non-government organizations, and fisherman mainstays were conducted in 2009. The purpose of these interviews was to gather information concerning the status of the Songkhla Lake fishery, recommendations for fishery management, and sustainability indicators.

3. Three focus group discussions among 18 individuals with expertise in four areas (five experts on environmental issues, two on economic issues, six on socio-community issues, and four on policy and institutional issues) were conducted. The purpose of these discussions was to brainstorm the status of the Songkhla Lake fishery, develop the indicators, verify the indicators and measurement method, and select the indicators.

\subsubsection{Analysis and Selection of Indicators}

The data collected by the questionnaire survey were analyzed using descriptive statistics. The data collected in interviews and expert meetings were analyzed, interpreted, and summarized and then used to support the selection of the indicators.

The criteria recommended in the expert meetings, together with those from a literature review weighted according to a rubric score (Popham, 1997), were applied to indicator selection, measurement method determination, and application of the indicators in the area. They were also verified through meetings and interviews with fishermen around Songkhla Lake.

\section{RESULTS}

\subsection{Criteria for Establishing Indicators}

Recommendation from the experts' focus group discussions suggested that the indicators should be useful for application at local levels and capable of application at the policy level. Therefore, the criteria for the development of the indicators for Songkhla Lake were analyzed and compared to those proposed by the FAO (1999). The criteria are that the number of indicators should be minimal; they should be easy to understand and apply, linked to sustainability, and effective and precise. 


\subsection{Selection of Songkhla Lake's Indicators}

On the basis of the results of the data collection described above, together with the weighting criteria for the selection of Songkhla Lake's indicators, ten significant indicators were identified. They are 1) catch per unit effort (CPUE), 2) salinity, 3) availability of economic aquatic animals, 4) water circulation, 5) water quality, 6) fishery productivity, 7) participation in conservation and restoration of fishery resources, 8) attitude toward fishing, 9) control of destructive fishing gear, and 10) regulation of fishing gear. The list of indicators, the measurement methods, and an explanation of each indicator were verified by fishermen through meetings and grouped into four areas - ecology, economy, community, and policy and institutional. Songkhla Lake's proposed monitoring indicators are described in detail in Table 1.

Table 1: Proposed Indicators for Sustainable Fishery in Songkhla Lake, Thailand

\begin{tabular}{|c|c|c|c|}
\hline $\begin{array}{l}\text { Sustainability } \\
\text { Components }\end{array}$ & Indicators & $\begin{array}{c}\text { Operational Definition and Units of } \\
\text { Measurement }\end{array}$ & Data Sources \\
\hline \multirow{5}{*}{ 1. Ecology } & $\begin{array}{l}\text { 1.1 Catch per unit } \\
\text { effort (CPUE) }\end{array}$ & $\begin{array}{l}\text { Catch per unit effort by shrimp traps and gill nets } \\
-\mathrm{Kg} / \text { day/unit of fishing gear }\end{array}$ & $\begin{array}{l}\text {-NICA } \\
\text {-MCRRC } \\
\text {-Fishermen }\end{array}$ \\
\hline & 1.2 Salinity & $\begin{array}{l}\text { Normal salinity in April (summer) and } \\
\text { November (rainy season) in the lower, middle, } \\
\text { and upper lake and Thale Noi } \\
\text {-Parts per thousand (ppt) }\end{array}$ & $\begin{array}{l}\text {-REO16 } \\
\text {-Fishermen }\end{array}$ \\
\hline & $\begin{array}{l}1.3 \text { Availability of } \\
\text { economic aquatic } \\
\text { animals }\end{array}$ & $\begin{array}{l}\text { Fishermen can catch economic aquatic animals in } \\
\text { the lower, middle, and upper lake and Thale Noi } \\
\text {-Number of species and quantity of aquatic } \\
\text { animals }\end{array}$ & $\begin{array}{l}\text {-NICA } \\
\text {-Fishermen }\end{array}$ \\
\hline & 1.4 Water circulation & $\begin{array}{l}\text { Normal water circulation in Songkhla Lake in } \\
\text { April (summer) and November (rainy season) } \\
\text {-Flux into and out of Songkhla Lake }\left(\mathrm{m}^{3} / \mathrm{s}\right)\end{array}$ & $\begin{array}{l}\text {-REO16 } \\
\text {-Fishermen }\end{array}$ \\
\hline & 1.5 Water quality & $\begin{array}{l}\text { Standard classification level of water quality } \\
\text { from the Notification of the Ministry of Natural } \\
\text { Resources and Environment, Thailand } \\
\text {-Dissolved oxygen and biochemical oxygen } \\
\text { demand (mg/l), coliform bacteria (MPN/ml) }\end{array}$ & $\begin{array}{l}\text {-REO16 } \\
\text {-Fishermen }\end{array}$ \\
\hline 2. Economic & Fishery productivity & $\begin{array}{l}\text { Production from fishing using all fishing gear } \\
-\mathrm{kg} / \text { day/household }\end{array}$ & $\begin{array}{l}\text {-NICA } \\
\text {-Fishermen }\end{array}$ \\
\hline \multirow{2}{*}{ 3. Community } & $\begin{array}{l}\text { 3.1 Community } \\
\text { participation }\end{array}$ & $\begin{array}{l}\text { Fishermen participate in restoration of protected } \\
\text { coastal area of Songkhla Lake. } \\
\text {-Area }\left(\mathrm{km}^{2}\right)\end{array}$ & $\begin{array}{l}\text {-NICA } \\
\text {-Fishermen }\end{array}$ \\
\hline & $\begin{array}{l}3.2 \text { Attitude to fishing } \\
\text { as an occupation }\end{array}$ & $\begin{array}{l}\text { Fishermen believe that this occupation is good } \\
\text { and want their families to be fishermen. } \\
\text {-Percentage of fishermen }\end{array}$ & -Fishermen \\
\hline \multirow{2}{*}{$\begin{array}{l}\text { 4. Policy and } \\
\text { Institutions }\end{array}$} & $\begin{array}{l}\text { 4.1 Control of } \\
\text { destructive fishing } \\
\text { gear }\end{array}$ & $\begin{array}{l}\text { Authorities are ready to control destructive } \\
\text { fishing gear, for example, push nets, } \\
\text { electrification gear, fish poisons, and surround } \\
\text { nets. } \\
\text {-Times/week }\end{array}$ & $\begin{array}{l}\text {-NICA } \\
\text {-Provincial fishery offices } \\
\text {-Fishermen }\end{array}$ \\
\hline & $\begin{array}{l}\text { 4.2 Regulation of } \\
\text { fishing gear }\end{array}$ & $\begin{array}{l}\text { Reduced number of shrimp traps and setting of } \\
\text { set-bag nets. } \\
\text {-Number of shrimp traps and setting of set-bag } \\
\text { nets }\end{array}$ & -Provincial fishery offices \\
\hline
\end{tabular}

Note: Abbreviation NICA: National Institute of Coastal Aquaculture, Songkhla, Thailand. MCRRC: Marine and Coastal Resource Research Center, Lower Gulf of Thailand. REO16: Regional Environmental Office No. 16 


\section{DISCUSSION}

\subsection{Overview}

The significant findings of this research, including the key indicators, recommendations, and guidelines for applying these indicators, are proposed to resolve problems and achieve sustainable management of fishing in Songkhla Lake.

\subsection{Indicators Specific to Songkhla Lake's Sustainable Fishery}

As a result of this research, 10 indicators of sustainable fishing in Songkhla Lake were recommended. Most of them were consistent with indicators suggested by several studies conducted in other countries; for instance, fishery indicators for the Yoron island group in Japan (Adrianto et al., 2005), coastal fishery indicators for Gungliau in Taiwan (Liu, 2005), indicators for monitoring the status of fishery resources in Tam Giang-CauHai Lagoon, Vietnam (Raakjaer et al., 2007), fishery indicators for a coral reef in Kenya (Mangia et al., 2007), and fishery indicators at the community level in Canada (Boyd and Charles, 2006). Only four are specific to Songkhla Lake the availability of economic aquatic animals, salinity, water circulation, and community participation in conservation and restoration of fishery resources.

\subsection{Application of the Indicators}

The indicators developed from this research are a useful tool for assessing the fishery in Songkhla Lake at the local level. They were designed to be practicable in the area. The following are the key success factors for applying these indicators.

- $\quad$ Establish a mechanism, such as a Songkhla Lake sustainable fishery development board, to integrate information management, planning, and cooperation among related sectors as well as to monitor fishery management. The board members should be representatives of stakeholders, including local administrative organizations, academicians, government organizations, and fishermen.

- Develop an integrated plan for sustainable fishery management in Songkhla Lake through cooperation among government organizations and related sectors. This integrated plan should consist of two parts: 1) a plan for monitoring sustainability and 2) a plan for the development of a sustainability fishery in Songkhla Lake.

\section{SUMMARY}

Ten indicators of sustainable fishery management in Songkhla Lake were determined. They are grouped into four categories, as follows:

- $\quad$ Ecological Indicators: These describe the physical and biological environmental qualities that support fishery resources in Songkhla Lake. They are the catch per unit effort (CPUE) by shrimp traps and gill nets, the normal salinity in Songkhla Lake, the availability of the economic aquatic animals that fishermen capture in each part of Songkhla Lake, the water quality in and around the lake, and the normal circulation of the lake which mixes freshwater, brackish water, and salt water.

- $\quad$ Economic Indicators: The income from fishery production should be sufficient for the basic needs of each fishing household.

- $\quad$ Community Indicators: These would demonstrate that fishermen are satisfied with this occupation and would like the next generation to be fishermen. In addition, they should increase their participation in the conservation and restoration of fishery resources in Songkhla Lake by expanding the protected area of the lake.

- Institutional Indicators: These describe effective management of fishery resources through control of destructive fishing gear, including push nets, electric fishing, and fish poisons, by appropriate restrictions imposed by the responsible organizations. In addition, the number of shrimp traps and set-bag nets should be reduced. 


\section{AUTHOR INFORMATION}

Mr. Narit Doungsuwan is a Ph.D. candidate in the Faculty of Environmental Management, Prince of Songkla University, Hat Yai, Songkhla, Thailand. $\mathrm{He}$ is a lake and basin management specialist. E-mail: mailnarit@gmail.com (Corresponding author)

Dr. Chatchai Ratanachai is an associate professor in the Faculty of Environmental Management, Prince of Songkla University, Hat Yai, Thailand. $\mathrm{He}$ is an environmental engineer and public policy specialist. E-mail: chatchai.ratanachai@gmail.com

Dr. Penjai Somgpongchaiyakul is an assistant professor in the Department of Marine Science, Faculty of Science, Chulalongkorn University, Bangkok, Thailand. She is a marine scientist. E-mail: penjai.s@chula.ac.th

Ms. Prapaporn Sangganjanavanich is a lecturer in the Faculty of Environmental Management Prince of Songkla University Hat Yai, Thailand. She is an environmental law specialist. E-mail: prapaporn.s@psu.ac.th

\section{REFERENCES}

1. Adrianto, L., Matsuda, Y., \& Sakuma, Y. (2005). Assessing local sustainability of fisheries system: a multicriteria participatory approach with the case of Yoron Island, Kagoshima prefecture, Japan. Marine Policy, 29(1) 9-23.

2. Boyd, H. \& Charles, A. (2006). Creating community-based indicators to monitor sustainability of local fisheries. Ocean \& Coastal Management, 49(5-6) 237-258.

3. Charles, A. 1994. Towards sustainability: the fishery experience. Ecological Economics, 11(3) 201-211.

4. $\quad$ Charles, A. (2001). Sustainable fishery system. Blackwell Science, Ltd.; London pp.370.

5. Choonhapran, A. (1996). Study on fisheries resources and population changes in Songkhla Lake: Case study on 3 fishing gears. Technical paper 18/1996, National Institute of Coastal Aquaculture (NICA), Songkhla, Thailand, pp. 1-32.

6. Coulthard, S., Johnson, D., \& McGregor, A. (2011). Poverty, sustainability and human wellbeing: A social wellbeing approach to the global fisheries crisis. Global Environmental Change, 21(2) 453-463.

7. Fletcher, R. (2002). National ESD Reporting Framework for Australian Fisheries: The 'How To' Guide for Wild Capture Fisheries. FRDC Project 2000/145, Canberra, Australia.

8. Food and Agriculture Organization of the United Nations. 1999. FAO technical guidelines for responsible fisheries No. 8 Indicators for sustainable development of marine capture fisheries. FAO, Rome.

9. Food and Agriculture Organization of the United Nations, (FAO). 2010. The State of World Fisheries and Aquaculture 2010. Rome, Italy, FAO, pp. 1-218.

10. Food and Agriculture Organization of the United Nations, (FAO). 2012. The State of World Fisheries and Aquaculture 2012. Rome, Italy, FAO, pp. 1-123.

11. Hosch, G., Ferraro, G., \& Failler, P. (2011). The 1995 FAO Code of Conduct for Responsible Fisheries: Adopting, implementing or scoring results? Marine Policy 35(6), 189-200.

12. Gallic (2002). Fisheries Sustainability Indicators: The OECD experience. "Tools for measuring (integrated) Fisheries Policy aiming at sustainable ecosystem" October 28-29, 2002, Brussels (Belgium).

13. Garcia, S. M., \& Staples, D. J. (2000). Sustainability reference systems and indicators for responsible marine capture fisheries: a review of concepts and elements for a set of guidelines. Marine and Freshwater Research 51(5) 385 - 426. Retrieved on 30 August 2011 from,

http://www.publish.csiro.au/nid/126/paper/MF99092.htm

14. Garcia, M., Staples, J. and Chesson,J. (2000). The FAO guidelines for the development and use of indicators for sustainable development of marine capture fisheries and an Australian example of their application. Ocean \& Coastal Management, 43(7) 537-556.

15. Liu, W. H., Ou, C. H. \& Ting, K. H. (2005). Sustainable coastal fishery development indicator system: case of Gungliau, Taiwan. Ocean and Coatal Management, 49, 237-258.

16. Mangia, C., Robertsb, M., \& Rodwell, D. (2007). Reef fisheries management in Kenya: Preliminary approach using the driver-pressure-state-impacts-response (DPSIR) scheme of indicators. Ocean \& Coastal Management, 50(5-6) 463-480. 
17. Marine and Coastal Resource Research Center (MCRRC), Lower Gulf of Thailand coast. (2008). The report of the operation work of the Department of fisheries in fiscal year 2008. Department of Marine and Coastal Resoucres, Misnistry of Natural Resources and Environment.

18. National Institute of coastal aquaculture. (2007). Annual Report in 2007.Department of Fishery. Ministry of Agriculture and Cooperatives. Department of Fishery, Ministry of Agriculture and Cooperatives,Thailand.

19. National Institute of coastal aquaculture. (2008). Annual Report in 2008.Department of Fishery, Ministry of Agriculture and Cooperatives, Thailand.

20. National Institute of coastal aquaculture. (2009). Annaul Report in 2009.Department of Fishery, Ministry of Agriculture and Cooperatives, Thailand.

21. National Institute of Coastal Aquaculture (NICA). (2010). Annual report2010. Bangkok: Department of Fishery, Ministry of Agriculture and Cooperatives, Thailand.

22. National Institute of coastal aquaculture. (2012). Report of the operation project of the recovery the fishery resource in Songkhla Lake Basin in 2004-2011. Retrieved on 2 May 2012 From, http://www.nicaonline.com/

23. Pomeroya, R., Parks, J., Richard Pollnac, R., Campsond, T., Genioe, E., Marlessy, C., Holle, E., Pidoh, M., Nissapai, A., Boromthanarat, S., \& Hue, T. (2007). Fish wars: Conflict and collaboration in fisheries management in Southeast Asia. Marine Policy, 31(6) 645-656.

24. Norse, A., Brooke, S., William W., Cheung, L. et al. 2012. Sustainability of deep-sea fisheries. Marine Policy, 36(2) 307-320.

25. Popham, J. 1997. What's Wrong and What's Right with Rubrics. Schools as Safe Havens, 55(2) 72-75.

26. Raakjaer, J., Son, M., Saehr, K., Hovgård, H., Thuy, N., Ellegaard, K., Riget, F. Thi, D., \& Hai, P. (2007). Adaptive fisheries management in Vietnam The use of indicators and the introduction of a multidisciplinary Marine Fisheries Specialist Team to support implementation. Marine Policy, 31(2) 143-152.

27. Regional Environmental Office no.16. (2009). Management of the Environmental quality in South east coast (Phatthlung Songkhal Pattanee Yala and Narativas). Office of the Secretary of Misnistry of Natural Resources and Environment, Thailand.

28. Sirichai, L. \& Doungsuwan, N. (2009). Final Report: The Development in The usage of resource in Songkhla Lake: A Study of Fisherfolk Community. Bankok: The Thailand Research Fund (TRF).

29. Srinivasan, T., Watson, R., \& Sumaila, R. (2012). Global fisheries losses at the exclusive economic zone level, 1950 to present. Marine Policy, 36(2) 544-549.

30. Tokrisna R., 2005. Situation of fisheries resource of Thailand \& Environmental and natural resource policy. Bangkok: National Health Foundation and Thai Health Promotion Foundation.

31. Ukwe, C., Ibe, C., \& Sherman, K. (2006). A sixteen-country mobilization for sustainable fisheries in the Guinea Current LargeMarine Ecosystem. Ocean \& Coastal Management, 49, 385-412.

32. UNESCO. (2006). A Handbook for Measuring the Progress and Outcomes of Integrated Coastal and Ocean Management. IOC Manuals and Guides, 46; ICAM Dossier, 2. Paris.

33. Vandermenlen, H. (1998). The development of marine indicators for coastal zone management. Ocean \& Coastal Management, 39(2) 63-71.

34. Zenetos, A., Streftaris, N., \& Lars-Henrik, L. (2002). An indicator-based approach to assessing the environmental performance of European marine fisheries and aquaculture. European Environment Agency European Environment Agency. Kongens Nytorv 6 DK-1050 Copenhagen. 
NOTES 